\title{
Some Features of English Fricatives Spoken by a Chinese Speaker*
}

\author{
Shaofan Wang \\ English Department of North China Electric Power University \\ Baoding, China
}

\begin{abstract}
Variation in interlanguage (IL) phonology is an important field for researching SLA. Generally speaking, the factors constraining the Chinese learners' pronunciation include "L1 transfer, markedness, margin length, sonority and linguistic environment. This paper will focus on the influence of L1 transfer on the English sounds produced by a Chinese speaker. Certainly, there are wide variations of pronunciation spoken by different people from different regions because China is a huge country and there exist many dialects throughout the whole country. Because the participant is a Mandarin Chinese speaker the research will mainly involves the effect of Mandarin Chinese on English sounds. The paper aims at providing a detailed analysis and trying to give a reference on the feature changes of English fricatives produced by Chinese English learners.
\end{abstract}

Keywords-L1 transfer; fricative; consonant

\section{INTRODUCTION}

In China there are millions of people learning English and variations of English language features of pronunciation become more and more noticeable. According to Weinberger (1994), in SLA, there may be substitutions for target sound. So variation in interlanguage (IL) phonology is an important field for researching SLA. Generally speaking, the factors constraining the Chinese learners' pronunciation include "L1 transfer, markedness, margin length, sonority and linguistic environment (Hansen, 2001, p.339-340)". L1 transfer refers to the influence of learner's first language on the knowledge of the second language development based on their similarities and differences. Markedness means the relationships between the two linguistic features which look like opposite. Margin length is the number of consonants in a coda. Margin length is a part of markedness because longer codas are thought to be more marked than the shorter ones. Sonority refers to the loudness of a sound compared with other sounds. At last, linguistic environment is defined as phonological environment for a sound. This paper will focus on the influence of L1 transfer on the English sounds produced by a Chinese speaker. Certainly, there are wide variations of pronunciation spoken by different people from different regions because China is a huge country and there exist many dialects throughout the whole country. Because the participant is a Mandarin Chinese speaker the research will mainly involves the effect of Mandarin Chinese on English sounds.

*The project item number 2014MS184 of the basic scientific research business expense of the Central University of North China Electric Power University
In view of L1 transfer, the different syllable structure between Chinese and English must be taken into consideration. One major difference is that in Mandarin Chinese only $/ \mathrm{n} /$ and $/ \mathrm{n} /$ can occur in the final position of a syllable. Another difference is English not only has voiced consonants but also voiceless consonants while the Mandarin Chinese has no voiced fricatives. So some speakers from China sometimes avoid producing such voiced fricatives /ð/, $/ \mathrm{z} /, / \mathrm{v} /$, or $/ 3 /$. In summary, Chinese is more restricted in syllable structure than that of English. This paper aims at providing a detailed analysis and trying to give a reference on the feature changes of English fricatives produced by Chinese English learners.

\section{LITERATURE REVIEW}

Hahsen (2001, p. 339-340) categorizes the linguistic constraints into five types: "L1 transfer, markedness, margin length, sonority and linguistic environment". The prior research points out L1 transfer is a predominant factor in shaping English pronunciation (Altenverg \&Vago, 1987; Benson, 1988). The linguists and researchers (e.g. Schmidt, 1987; Major, 2001, Dewaele, 2004) suggest that the L1 transfer factor can be classified as internal and external factors. Deterding (2006) and Rau (2009) both explore the feature changes of English fricatives caused by Mandarin Chinese from L1 transfer perspective. Based on the prior research and collected data, this paper will make a discussion about the English fricatives produced by a Mandarin Chinese participant.

\section{METHODOLOGY}

A 29-year-old male speaker of Mandarin Chinese was chosen as the participant in this study. The participant grew up in the city and graduated from one of top universities in China. Now working as a college teacher he has passed the National Mandarin Test (In Mainland China, passing the National Mandarin Test is a necessary qualification for every teacher). His urban and educational background can provide him with a more advantageous environment for English study compared with many English learners from rural areas. Besides, he claims that he mainly speaks Mandarin with his friends and colleagues in the daily life because of a lack of dialect context. So although this participant comes from Shandong Province, the northeastern part of China, and we cannot exclude the influence of area totally, the influence of 
the dialect on the pronunciation has been considered to try to be reduced as little as possible.

The study needs the participant to read a "shopping list" (See Appendix 1) and the reading will be audio recorded. The "shopping list" (Swan \& Smith, 1987, p. 265) is borrowed as the reading text to collect the spoken data from ELT learners because it contains all the phonemes of British English. It is a general diagnostics reading text. However, in view of the research purpose, this text still has its own flaws:

$/ \theta /$ occurs in the initial position and never occurs in the final position. There is no word with /z/ in the initial and middle position. This sound only happens at the end of the word such as apples, please and potatoes. These and that are the only instances about sound /ð/. Meanwhile, /ð/ only occurs in the initial positions. Then the recording will be transcribed phonetically word-by-word in the International Phonetic Alphabet (IPA). After transcription 16 lines were picked up as the data to analyze and summarize the features of English spoken by this Chinese speaker. The transcription of these 16 lines (See Appendix 2) is categorizes into the accurate pronunciation and the feature change spoken by the participant. The accurate pronunciation refers to the nativelike production while feature change means "the participant produces consonants in an articulatorily different manner or place (Hansen, 2001,p.338)". For example, the participant produced the voiceless dental fricative $/ \theta /$ as the voiceless alveolar fricative/s/, so the change of articulation place from dental to alveolar caused the production of the word three as / sri : /. Another common articulation change is devoicing, which is a process where a voiced consonant is produce voicelessly as the production of /s/ instead of /z/ in the word pickles.

\section{DATA AND ANALYSIS}

\section{A. Voiceless Dental Fricative / $\Theta /$}

In the reading text, there are only five words with the production of the voiceless dental fricative $/ \theta /$, which occur in the initial position rather than the final position. So this text cannot provide us with the enough data to discuss all potential and significant factors to influence the accurate production of the sound $/ \theta /$.

TABLE I. Factors IN The TeXt to Influence the ACCURATE Production of / $\Theta /$

\begin{tabular}{lcc}
\hline Factor & Sample words & Speaker's production \\
\hline $\begin{array}{l}\text { Vowel following an onset } \\
\text { (th) }\end{array}$ & & \\
\hline Close front vowel & thick & $/ \mathrm{s} /$ \\
& thin $/ /$ & $/ \mathrm{s} /$ \\
Diphthong /æ/ & thanks & $/ \mathrm{s} /$ \\
Close front vowel after & three & \\
consonant cluster thr & &
\end{tabular}

It is important to separate initial $/ \theta /$ from final $/ \theta$ / because they may be different. For example, initial $/ \theta /$ tends to be produced as $/ \mathrm{t} /$ but in final position $/ \theta$ / usually becomes /f/ (Deterding \& Poejosoedarmo, 1998; Wee, 2004). So although there is no instance of final $/ \theta /$ in the reading text, we still cannot exclude the influence of positional change on the accurate production.

From "Table I" the low accuracy rate shows that the voiceless dental fricative $/ \theta /$ is often replaced by the voiceless alveolar fricative /s/. In Chinese Mandarin Area, /s/ as the substitution of $/ \theta /$ is a common phenomenon for many English learners. L1 transfer may explain partly this phenomenon. In English, most consonants can occur in the first position of a syllable as well as in the final position with only a few exceptions such as $/ \mathrm{h} / \mathrm{and} / \mathrm{y} /$.But in Mandarin, the number of consonants occurring at the start of a syllable is larger than that occurring in the final position. According to Deterding and Poedjosoedarmo (1998), all Mandarin syllables should have the following structure:

- an optional initial consonant

- an optional approximant

- an obligatory vowel peak

- an optional final nasal

In modern Mandarin, compared with the initial consonants, only alveolar nasal /n/ and velar nasal / $\mathrm{y} /$ occur in the final positions. The consonants occurring in the first position are shown in "Table II".

TABLE II. SOURCE: DETERDING \& PoedJosoedARMO ,1998, P.194

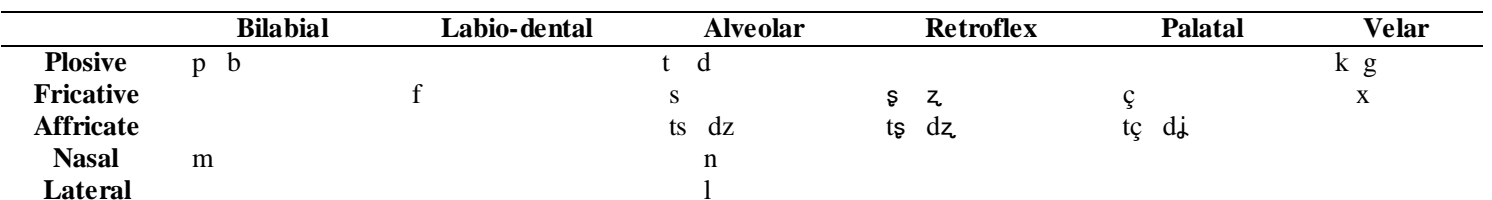

Based on the above discussion, it is not difficult to see in Mandarin there is no voiceless dental fricative $/ \theta /$ in the syllables no matter in the initial or final position. Instead, voiceless alveolar fricative /s/ can occur in the first position for example, $/ \mathrm{s} \gamma /$ ('four'). So because of the influence of modern Mandarin and a lack of native-like language context, the participant tended to produce/s/, which he thought was the most similar sound of $/ \theta /$, as the substitution of $/ \theta /$ when this sound is in the initial position of the syllable and the vowels after the onset (th) inhibit the accurate production of (th) include close front vowel /l/ (e.g. thick and thin), close 
front vowel /i:/ after the consonant cluster (thr) ( e.g. three) and the diphthong /æ/ (e.g. thanks).

\section{B. Voiced Dental Fricative/円/}

Two words, these and that, with voiced dental fricative /ð/ appear in the reading text. However, both occur in the initial positions. Besides, because of carelessness, the participant misproduced these (Line 2) as three. So there is only one word left to us for analysis. The participant produced voiced alveolar fricative /z/ to substitute /ð/ and the vowel following the onset (th) is the diphthong /æ/. In view of Table 2, dental fricatives never exist in the consonant inventory of modern Mandarin Chinese. Therefore, from the instance of that, we can assume that influenced by the syllable structure of the Mandarin the participant may tend to produce voiced alveolar fricative $/ z /$ in place of voiced dental fricative /ð/ when /ð/ occurs in the initial position of one syllable.

\section{Voiced Alveolar Fricative /Z/}

The big distinction between Mandarin Chinese and English is that all Chinese stops, affricates, and fricatives are voiceless while English has not only voiced but also voiceless consonants. Another major difference is that Mandarin Chinese only allows $/ \mathrm{n} /$ and $/ \mathrm{n} /$ to occur in the final positions. Mandarin Chinese is more restricted in syllable structure than that of English. The allowed syllable structures in Mandarin Chinese include vowel (V), consonant vowel $(\mathrm{CV})$, consonant-vowel-nasal $(\mathrm{CVN})$ and vowel nasal (VN) (Cheng, 1973). There are no consonant clusters in Mandarin Chinese. On the contrary, codas in English are common and complex with up to four consonants in a row (Jensen,1993). So the most salient feature of pronunciation in this study is how the participant produced codas in English syllable structure. Based on the analysis, it is found that when the voiced alveolar fricative $/ \mathrm{z} /$ is in the final position of codas, especially in plural suffixes of nouns, the voiceless alveolar fricative /s/ was overwhelmingly used to substitute the sound $/ \mathrm{z} /$.

In English, if a noun is ended with $/ \mathrm{s} /, / \mathrm{z} /, / \mathrm{S} / \mathrm{,} / \mathrm{z} / \mathrm{,} \mathrm{t} \mathrm{\textrm {J }} /$, or $/ \mathrm{d} 3 /$, the plural suffix is produced as $/ \mathrm{zz} /$ or $/ \mathrm{\partial z} /$. When a noun ends with a voiced sound, the plural suffix is pronounced as $\mathrm{z} /$. Otherwise, if a noun ends with a voiceless sound, the plural suffix will be produced as /s/ (Deterding \& Poedjosoedarmo, 1998).

There is no word with /z/ in the initial and middle position in this reading text. / $\mathrm{z} /$ only occurs in the final position. Based on "Table III", the accurate production of $/ \mathrm{z} /$ in the final position occupies $46.7 \%$ in the all productions. The comparatively low accuracy rate shows that the alveolar nasal consonant $/ \mathrm{n} /$ contributes most to the accurate production of $/ \mathrm{z} /$. Instead, the factor inhabits the accurate production most is dark /1/ (e.g. apples and pickles).

TABLE III. THE REALIZATION OF THE CONSONANT /Z/ OF THE WORD IN THE READING TEXT

\begin{tabular}{|c|c|c|c|}
\hline Sample words & Position & Speaker's pronunciation & The sound before $/ z /$ \\
\hline things & final & $/ \mathrm{s} /$ & velar nasal consonant $/ \mathrm{y} /$ \\
\hline please & final & $/ \mathrm{s} /$ & close front vowel /i:/ \\
\hline kilos & final & $\mid z /$ & diphthong /ou/ \\
\hline beans & final & /z/ & alveolar nasal consonant $/ \mathrm{n} /$ \\
\hline tins & final & /z/ & alveolar nasal consonant $/ \mathrm{n} /$ \\
\hline pickles & final & $/ \mathrm{s} /$ & dark /1/ \\
\hline peppers & final & $/ \mathrm{s} /$ & mid central vowel /ə/ \\
\hline apples & final & $/ \mathrm{s} /$ & dark /1/ \\
\hline tomatoes & final & $/ \mathrm{s} /$ & diphthong/pu/ \\
\hline bananas & final & /z/ & mid central vowel /ə/ \\
\hline Sample words & Position & Speaker's pronunciation & The sound before $/ \mathrm{z} /$ \\
\hline tubes & final & $/ \mathrm{s} /$ & bilabial plosive consonant/b/ \\
\hline potatoes & final & $/ \mathrm{s} /$ & diphthong/əu/ \\
\hline kinds & final & /z/ & alveolar nasal consonant $/ \mathrm{n} /$ \\
\hline pears & final & $/ z /$ & diphthong/ı/ \\
\hline cheese & final & $/ z /$ & close front vowel /i:/ \\
\hline
\end{tabular}

\section{Voiced Labiodental Fricative /V/}

Chang (1987) claims speakers from China sometimes use voiced labial-velar approximant /w/ to substitute /v/. But /w/ does not occur in the final position of the syllable neither in Chinese nor English. So /w/ usually substitutes the initial /v/ rather than the mid or final $/ \mathrm{v} /$. Unfortunately, the reading text embraces no instance having initial / $/ \mathrm{v}$. So in this study we cannot find the substantial data to prove his findings. In contrast, it is found that $/ \mathrm{v} /$ in the final position is sometimes replaced by voiceless labiodental fricative /f/.
Integrating "Table IV" with "Table V", it is not difficult to find that the participant's production of /f/ in the word of is influenced by the spelling rules. In English, the letter $\mathrm{f}$ in the word is usually pronounced as /f/ as shown in "Table $\mathrm{V}$ ”. Influences by such rules, it is very common for Chinese learners to pronounce /of/ rather than /ov/ for the word of.

The Mandarin Chinese has no voiced fricatives. So some English learners sometimes avoid producing /v/. /v/ in the word olive occurs in the final position, which may give a partial explanation why the participant produced /'olif/ not /'olıv/. 
TABLE IV. THE REALIZATION OF THE CONSONANT/V/ OF THE WORD IN THE READING TEXT

\begin{tabular}{|l|l|l|l|}
\hline $\begin{array}{c}\text { Sample } \\
\text { words }\end{array}$ & Position & $\begin{array}{c}\text { Speaker's } \\
\text { pronunciation }\end{array}$ & $\begin{array}{c}\text { The sound before } \\
\text { /v/ }\end{array}$ \\
\hline of & final & /f/ & diphthong/ou/ \\
\hline olive & final & /f/ & close front vowel /// \\
\hline
\end{tabular}

TABLE V. THE REALIZATION OF THE CONSONANT/F/ OF THE WORD IN THE READING TEXT

\begin{tabular}{|l|l|l|}
\hline \multicolumn{1}{|c|}{$\begin{array}{c}\text { Sample } \\
\text { words }\end{array}$} & \multicolumn{1}{|c|}{ Position } & \multicolumn{1}{c|}{$\begin{array}{c}\text { Speaker's } \\
\text { pronunciation }\end{array}$} \\
\hline if & final & /f/ \\
\hline few & initial & /f/ \\
\hline foil & initial & /f/ \\
\hline half & final & /f/ \\
\hline coffee & middle & /f/ \\
\hline four & initial & /f/ \\
\hline Sample words & Position & $\begin{array}{l}\text { Speaker's } \\
\text { pronunciation }\end{array}$ \\
\hline useful & middle & /f/ \\
\hline first & initial & /f/ \\
\hline five & initial & /f/ \\
\hline flour & initial & /f/ \\
\hline
\end{tabular}

\section{CONCLUSION}

Some salient English fricative features of pronunciation spoken by a Mandarin Chinese speaker have been summarized here. But because there are many dialects throughout China, the replacement of $/ \theta /, / \delta /, / \mathrm{z} /$, or $/ \mathrm{v} /$ may differ for people from different regions of China. The feature variations of English pronunciation in China are really very complex and deserve our further exploration.

\section{REFERENCES}

[1] Altenberg, E. P. \& Vago, R. M. (1987). Theoretical implications of an erro analysis of second language phonology production. In G. Ioup, S. $\mathrm{H}$. Weinberger Interlanguage phonology:The acquisition of a second language sound system (pp. 151-163). Cambridge: Newbury House.

[2] Benson, B. (1988). Universal preference for the open syllables as an independent process in interlanguage phonology. Language Learning, 38 (2), 221-235.

[3] Chang, J. (1987). Chinese speaker. In M. Swan, B. Smith Learner English: A teacher's guide to interference and other problems (pp. 224-237). Cambridge: Cambridge University Press.

[4] Cheng, C. C. (1973). A synchronic phonology of Mandarin Chinese, The Hague: Mouton.

[5] Deterding, D. H. \& Poedjosoedarmo, G. R. (1998). The sound of English: Phonetics and phonology for English Teachers in Southeast Asia. Singapore: Prentice Hall.

[6] Deterding, D. H. (2006). The pronunciation of English by speakers from China. English World-Wide, 27 (2), 175-198.

[7] Dewaele, J.(2004). Retention or omission of the ne in advanced French interlanguage: The variable effect of extralinguistic factors. Journal of Sociolinguistics, 8 (3), 433-450.

[8] Hansen, J. G. (2001). Linguistic Constraints on the acquisition of English syllable codas by native speakers of Mandarin Chinese. Applied Linguistics, 22 (3), 338-365.
[9] Jensen, J. T. (1993). Current issue in linguistic theory,99: English phonology. Amsterdam: John Benjamins Publishing Company.

[10] Major, R. C. (2001). Foreign accent: The ontology and phylogeny of second language phonology. Mahwah,NJ: Lawrence Erlbaum.

[11] Rau, D. V., Chang, H. A. \& Tarone, E. E. (2009). Think or sink: Chinese learners' acquisition of the English voiceless interdental fricative. Language Learning, 59 (3), 581-621.

[12] Schmidt, R. W. (1987). Sociolinguistic variation and language transfer in phonology. In G. Ioup, S. H. Weinberger Interlanguage phonology: The acquisition of a second language sound system (pp. 365-377). Cambridge: Newbury House.

[13] Weinberger, R. (1994). Theoretical foundational of second language phonology. Unpublished doctoral dissertation, University of Washington.

\section{APPENDICES}

Appendix 1

- If you are going shopping, John

- could you get me these few things, please?

- Three kilos of green beans,

- six tins of mixed pickles,

- ten red or yellow peppers,

- a bag of apples,

- half a carton of large tomatoes,

- a pot of hot coffee,

- four sorts of corn,

- a cookery book,

- a bunch of bananas and some butter,

- two tubes of that useful new glue,

- some first early potatoes,

- eight paper plates,

- a whole Dover sole,

- five kinds of white wine,

- a pound of brown flour,

- some olive oil and cooking foil,

- some beer, not too dear,

- some pears to share,

- some ham to cure, if you are sure it's pure,

- and a measure of orange juice,

- and a chunk of Dutch cheese, cut thick or thin.

- Thanks very much, John. 


\section{Appendix 2}

\begin{tabular}{|c|c|}
\hline Target Pronunciation & Transcription of Learner's Pronunciation \\
\hline $\begin{array}{l}\text { if you are going shopping, John } \\
\text { /If jo : ə 'gbuin 'Jpping dbon/ }\end{array}$ & 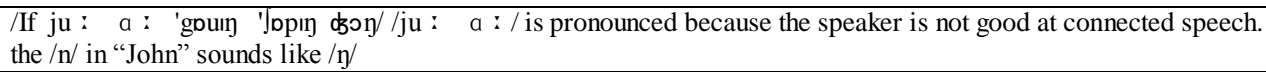 \\
\hline $\begin{array}{l}\text { could you get me these few things, } \\
\text { please? } \\
\text { /kUd ju : get mi : ði : z fju : } \\
\theta \text { I yz pli : z/ }\end{array}$ & $\begin{array}{l}\text { /kod ju : get mi : sri : fju : sins pli : s/ } \\
\text { the word "these" is mistaken by "three" and is produced as / sri : / } \\
\text { in the word "things", (th) is produced as /s/ and (s) is pronounced as /s/ } \\
\text { /z/ in "please" is produced as /s/ }\end{array}$ \\
\hline $\begin{array}{l}\text { Three kilos of green beans, } \\
\text { / } \theta \text { ri : 'ki : louz bv gri : n bi : nz/ }\end{array}$ & $\begin{array}{l}\text { /sri : 'ki : louz of gri : n bi : nz/ } \\
\text { / } \theta \text { / in "three" sounds like /s/ } \\
\text { the consonant / v /in "of" is produced as /f/ }\end{array}$ \\
\hline $\begin{array}{l}\text { six tins of mixed pickles, } \\
\text { / sıks tınz pv mıkst pıklz/ }\end{array}$ & $\begin{array}{l}\text { / seeks tınz DV meıkst pıkls/ } \\
\text { the vowel /ı/in "six" sounds like diphthong /el/ } \\
\text { the consonant / v /in "of" is produced as /f/ } \\
\text { / / /in "mixed" is produced as / el/ } \\
\text { /z/ in "pickles" is pronounced as /s/ }\end{array}$ \\
\hline $\begin{array}{l}\text { ten red or yellow peppers } \\
\text { /ten red ऽ: 'jelpu pepəz/ }\end{array}$ & $\begin{array}{l}\text { /ten red o: 'jelpu peipos/ } \\
\text { the /e/ in "peppers" is produced as/el/ } \\
\text { the / z/ in "peppers" is pronounced as / s/ }\end{array}$ \\
\hline $\begin{array}{l}\text { a bag of apples } \\
\text { /ə bæg DV 'æplz/ }\end{array}$ & $\begin{array}{l}\text { /a bæg of ' æpo: s/ } \\
\text { / æpo : s/for "apples" } \\
\text { the /pl/ is produced as / po : / } \\
\text { 'the / z/ is pronounced as/ s/ } \\
\text { the consonant / v /in "of" is produced as /f/ }\end{array}$ \\
\hline $\begin{array}{l}\text { half a carton of large tomatoes } \\
\text { /ha: f a 'ka: tn ov la: ds to'ma } \\
: \text { tbuz/ }\end{array}$ & 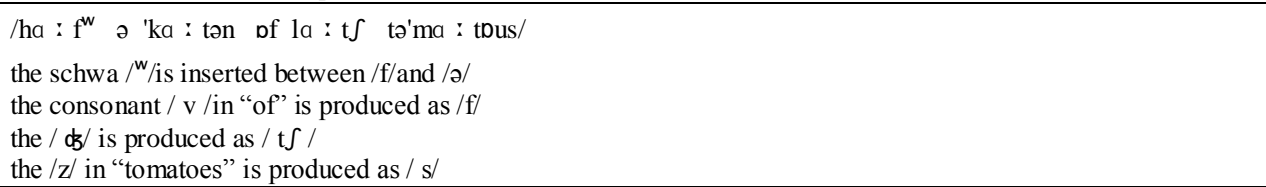 \\
\hline $\begin{array}{l}\text { a pot of hot coffee, } \\
\text { /a ppt pv hpt 'kpfi/ }\end{array}$ & $\begin{array}{l}\text { /ə pot of hot 'kpfi/ } \\
\text { the consonant / v/in "of" is produced as /f/ }\end{array}$ \\
\hline 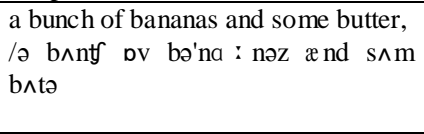 & 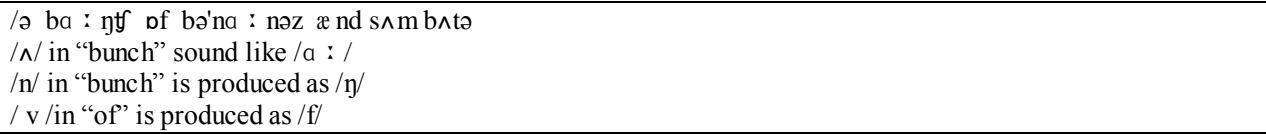 \\
\hline $\begin{array}{l}\text { two tubes of that useful new glue, } \\
\text { /tu : tju : bz ov dæt 'ju : sfol } \\
\text { nju: glu : / }\end{array}$ & $\begin{array}{l}\text { /tu : tju : bs of zæt 'ju : sfol nju : glu : / } \\
\text { /z/ in "tubes" is produced as /s/ } \\
\text { / v/in "of" is produced as /f/ } \\
\text { /ð/ in "that" is substituted by/z/ }\end{array}$ \\
\hline $\begin{array}{l}\text { some first early potatoes, } \\
/ \mathrm{s} \wedge \mathrm{m} \text { f3 }: \text { st ' } 3: 11 \text { po'te I tbuz/ }\end{array}$ & 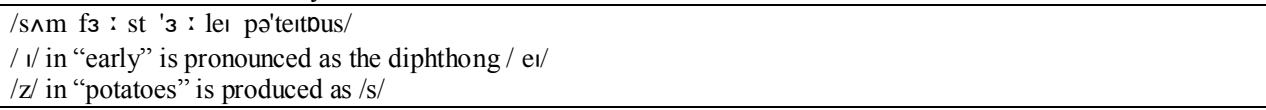 \\
\hline $\begin{array}{l}\text { five kinds of white wine, } \\
\text { /fa।v kaIndz Dv walt wa।n/ }\end{array}$ & $\begin{array}{l}\text { /faiv kainz of wait wain/ } \\
\mathrm{d} / \text { in "kinds" is omitted } \\
\text { / v /in "of" is produced as /f/ }\end{array}$ \\
\hline $\begin{array}{l}\text { a pound of brown flour } \\
\text { /a paund DV braun 'flavə/ }\end{array}$ & $\begin{array}{l}\text { /o pa: pd of bron flo : / } \\
\text { the /av/ in "pound" is produced as /a : / } \\
\text { the / av/in "brown" is produced as /o/ } \\
\text { the consonant / } \mathrm{v} / \text { in "of" is produced as /f/ } \\
\text { the /avə/ in "flour" is pronounced as / o : / }\end{array}$ \\
\hline 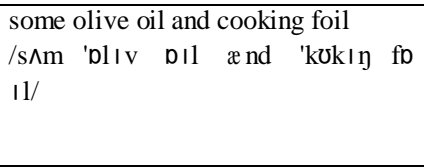 & 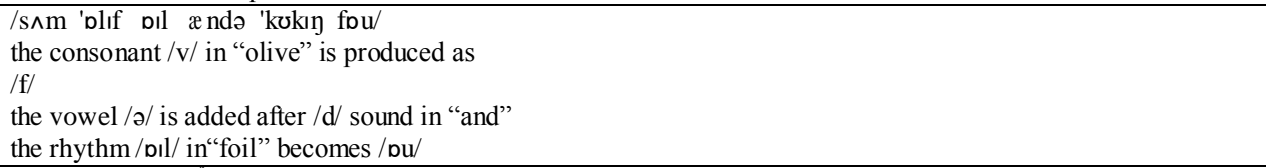 \\
\hline $\begin{array}{l}\text { some pears to share, } \\
\text { /s^m pıəz tu : } \int \mathrm{e} / \mathrm{l}\end{array}$ & $\begin{array}{l}\text { /s^m pıəs tu: leə/ } \\
\text { /z/ in "pears" is substituted by /s/ }\end{array}$ \\
\hline 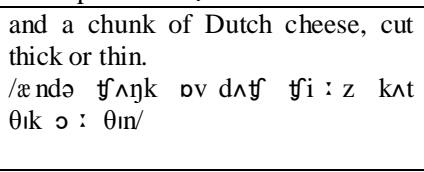 & 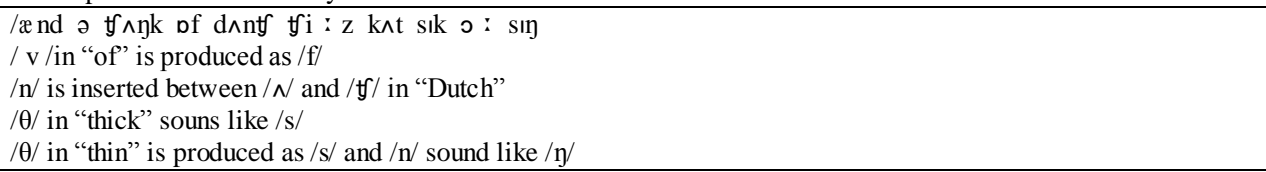 \\
\hline 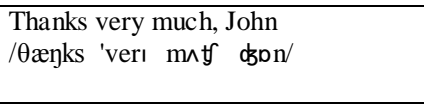 & $\begin{array}{l}\text { /sæyks verı m^t' dbpy/ } \\
\text { the } / \theta \text { / in "thanks" sounds like /s/ } \\
\text { the / } \mathrm{n} / \text { in "John" sounds like / } \mathrm{y} /\end{array}$ \\
\hline
\end{tabular}

